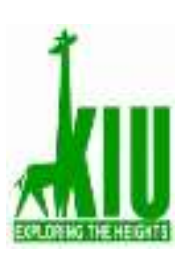

KIU Journal of Humanities Copyright $\odot 2019$

Kampala International University ISSN: 2415-0843; 4(1): 49-55

\title{
Globalization and Awka Personal Names: An Anthropolinguistic Study
}

\author{
IFEOMA EMMANUELA UDOYE \\ Chukwuemeka Odumegwu Ojukwu University, Igbariam Campus, Nigeria.
}

\begin{abstract}
This paper examines the effect of globalization and modernity on Awka personal names from anthropolinguistic perspective. Ten names were given in-depth analysis based on primitivism theory by Lovejoy and Boas (1935). The study indicates that most Awka names tell stories about the people. Through names, it is possible to understand the Awka man's simple way of life. Finally, it is discovered that globalization has destroyed most of the indigenous names making the people to embrace English names or names that do not reflect their culture and tradition because the people believe that such names will help them to keep abreast with the modern times.
\end{abstract}

Keywords: Globalization, Awka, names, culture, primitive, Ozo

\section{Introduction}

Globalization has become an issue of international discourse from various perspectives. Westerners see globalization as the best thing that could ever happen to man, especially to Africans. They believe that globalization will improve Africa's total way of life particularly in the area of poverty reduction. To Africans, the negative impact of globalization has aroused many research by scholars such as (Enojo, 2008; Udoh, 2007; Akpotor 2005). United Nations 1999 as cited in Enojo, (2008:47) opines that "people's lives around the globe are linked more deeply, more intensely, more immediate than ever before to acquiring the good and the bad things of life". The economic, social and political revolution brought about by globalization in the $21^{\text {st }}$ century is believed to have triggered radical changes in all the spheres of life of the ordinary Awka man particularly; his culture and names ( Onukawa, 2000; Obeng, 1998; Mmadike, 2004). The arrival of globalization struck the Awka man like a hurricane, they had many elements of culture which were displayed in the names they bear. Their belief, philosophy, history, festivals, hopes and aspirations are encapsulated in their names. Makoni and Pfukwa, (2010:199) posit that "names of all kinds are social documents which fix a person's position in the social relations to other members of society". They concluded that names are vital communicative resource. Awka names are numerous and reflect all the aspects of their life. Awka names can be classified under the following categories: market days, gods, love for children, death, sorrow and suffering, philosophy of life, belief in God Almighty, complexion, remembrance and reincarnation, circumstances surrounding the birth, parents financial state, man's relationship with man, cultural attributes, hopes and aspirations (Udoye, 2018). This paper discusses ten Awka names before globalization and after globalization and further examines its effect on present day Awka culture .

\subsection{Awka People}


Awka people belong to the major group of Igbo language speakers found in south-eastern part of Nigeria. The name Awka refers to both the people and their dialect. Their dialect and culture are quite unique to them. They claim Okikanube 'he who is pre-eminent with the spear' as their ancestral god and they are mostly blacksmiths. Few studies have been carried out on the grammar of the dialect and names including Udoye $(2011,2018)$ studies on Awka names from semantic and sociolinguistic points of view, no study has been done on names using primitivism theory thus, the present study tries to fill this gap.

\subsection{Awka Indigenous Culture}

Awka tradition boasts of rich cultural heritage often geared towards entertaining, sustaining and maintaining culture like the $O z o$ title and festivals organized by the people. Culture distinguishes members of one society from another and is often unique. Culture serves as the peoples' conscience and modifier of behaviour. Culture is made by man to regulate and guide members of the society. In traditional Awka setting, certain elements of culture exist such as $O z o$ title taking and Imoka festival. A feast day is a day to worship the named god and also is a day of rest. Onwa Nvu "first month"
"Egwu Imoka" is the most glowing of all the feasts. Imoka saved the Awka people from intercommunity war through the shriek made by the black monkeys which alerted the people. This singular act by the monkeys made the people to dedicate the monkeys to Imoka hence they do not kill monkeys. History reveals that it is a symbol of Imoka. Offodile, (1998) asserts that Egwu Imoka is celebrated on the first Afvor market day following the $21^{\text {st }}$ day of the moon. The feast lasts for five days. During the celebration, nobody dared to go to the farm or do any type of work. Imoka detests people who undertake any type of farming or other type of activity that will tarnish the image of Awka during its celebration. For this reason, he visits them with fire which usually burns their houses. Another fascinating festival is Ede-Ozo. Ede$O z O$ is a cocoa yam feast in honour of $O z O$ titled men. $O z O$ titled men are seen as symbols of dignity, honour and respect. In fact, the title taking is the most expensive and prestigious of all the titles in Awka and it is not an all comers affair. In the twelve calendar months, there is always a feast in every month which is observed as public holiday. Every feast in Awka is celebrated on Afvor day except Chi which is celebrated on Oye day. This can be summarized in the table below:

\begin{tabular}{|l|l|l|l|}
\hline & Awka Calendar & Feast & Month \\
\hline 1. & Onwa Nvu & Egwu Imọa & May \\
\hline 2. & Onwa Ibuo & Onwa Ukwu & June \\
\hline 3. & Onwa Ito & Onwa Fulu Manfu & July \\
\hline 4. & Onwa Ino & Obubu Amanulu & August \\
\hline 5. & Onwa Ise & Chi & September \\
\hline 6. & Onwa Ishii & Alor & October \\
\hline 7. & Onwa Asaa & Otite & November \\
\hline 8. & Onwa Asatọ & Owuwaji & December \\
\hline 9. & Onwa Teghete & Ede Òzọ & January \\
\hline 10. & Onwa Illi & Egwu Alụshi & February \\
\hline 11. & Diokpala Onwa Illi & Egwu Alụshi continued & March \\
\hline 12. & Onwa Ogugu Aro & Edemuọ & April \\
\hline
\end{tabular}

Table 1: Awka Calendar

\subsection{Awka Names before Globalization}

Awka names are a summary of their culture. Culture infuses a certain level of pride in a man. It serves as a link between the past and the present. Cultural values are inculcated in language, festivals, traditions etc. Awka names are symbolic and the people attach great importance to their names. Before a name is given to a child, certain observations were made such as the child's background, family history, situation surrounding the birth, religion of the child's parents and the festival or. Names are not 
just tags, but, vehicles used to understand cultural activities of the people.

\section{Theoretical Framework}

Primitivism theory is basically concerned with the way our fore-fathers lived. It was propounded by Lovejoy and Boaz in 1935 . According to Staszak (2004:353) primitivism is characterized by "a rejection of canonic western art, perceived as inauthentic". Primitivism is simply an attempt to promote our fore-fathers lives which appeared to be simpler and freer than the modern and civilized world. The life of primitive people is a representation of the state of nature and nature in its totality is lost when external additions are added. Lovejoy and Boaz in their book Primitivism and related ideas in antiquity grouped primitivism into two: chronological and cultural primitivism. However, this work uses cultural primitivism to advocate that simple life is better and less complicated than modern life. This idea is supported by Romantic movement and writings of early twentieth century writers such as Fairchild in his book the Noble Savage 1928) which promotes love for nature. Cultural primitivism is divided into two: soft and hard primitivism. Hard primitivism upholds natural life that is free from any civilized process such as arts and sciences. Life of primitive people is fun and free from war or atrocities. The people are always happy and content with the little they have while soft primitivism promotes a stress free and friendly life (Dictionary of the history of ideas, 1968).

\section{Literature Review}

Mmadike (2014) studies Ala names from anthropolinguistic perspective. The summary of his findings is that modernity and Christianity have great impact on Ala names. Ala names are no longer first names as they used to be but are now surnames. The work is different from the present work which studies Awka names specifically while Mmadike's work is based on Ala names.

Udoye (2018) does a semantic classification of Oka dying anthroponyms. She observed that most indigenous Oka personal names give information about the circumstances surrounding the birth of a child. Hence, names have historical and social influence on the individual. The work is similar to the present work because both looked at the effect of contact and some examples of Awka dying names are used in the present work. It differs from this work because the earlier work focused on the classification of Oka dying names while the present researcher looks at the effect of globalization on Awka names using primitivism theory.

Obeng (1998) considers Akan death prevention names from pragmatic and structural perspective. He discovered that Akan as well as other African death prevention names are given to trick death and to lament the death of children who had died earlier. However, Obeng observed that westernization, Christianity and improved medical care have greatly affected Akan names in general and death prevention names in particular. Obeng's work is related to the present work because both look at the influence of modernity on names. The work is however different from this work in the sense that the previous work looked at Akan death prevention names while the present researcher's major focus is on Awka names.

Mensah (2015) studies the structure of Ibibio death prevention names. He discovered that Ibibio death prevention names have open ended and deeply versatile syntax. He further observed that the structure of Ibibio prevention names is different from ordinary Ibibio names. The work is different from the present work while the previous work looked at Ibibio death prevention names, the present work examines Awka names.

\section{Data Presentation and Analysis}

Ten names have been selected for discussion. The names are analyzed based on the theoretical framework as follows:

\section{Nwajiobu (my child holds my lineage)}

Nwajiobu denotes a male child. Igbos believe that a male child is the only one that is allowed 
by culture to inherit his father's $o b u$ 'the nucleus of the family' (Udoye, 2018). Where there is no male child in the family, the man's elder brother inherits it. This is hard primitivism because the child grows up being content that he will inherit the $o b u$ and continue with the family lineage and the child is satisfied with the simple lifestyle without the stress of arts and sciences. A male child who succeeds his father is entitled to all his father's properties including the house the father lived in before he died. Succession is mainly by seniority. However, when the eldest son dies before his father, the second son automatically succeeds the father when the father dies. In a situation whereby a woman is unable to bear male children, the woman can marry another woman who could be impregnated by anybody in an attempt to bear male children. All the children born by the woman belong to the man and are entitled to succeed the man. Although the people attach great importance to male children, women are given rights such as inheritance. An unmarried woman is entitled to a plot of land from her father's estate. She is also entitled to farm in the community land. Another interesting privilege given to the Awka woman is that when a woman gives birth out of wedlock, the child automatically becomes the legitimate child of her father and becomes part of the man's male children. It is important to point out that although such a privilege is given, Awka people frown at such behaviour. Unlike the situation now, where the first son will abandon the $o b u$ and move to another country where he takes up the culture of the people hence, he sees his father's culture as timid and unprogressive. Again, during the primitive era, barren women did not leave their husbands' houses because of childlessness as practiced today but, they married women for their husbands and still catered for those children who automatically become theirs. Hence, divorce due to childlessness was not popular as it is now because the people enjoyed peace through simple decisions that they made.

\section{Ekemma (Eke day is beautiful)}

The name Ekemma shows that the name giver eulogizes nature and aesthetics of Eke day. People pray to the god of the market day to bless the day so that buyers and sellers at the market will have a peaceful market day devoid of trouble and calamities. Anybody who stole at the market place had to contend with the god guiding the market day. People avoided offending the god of the market day by not stealing. This name is no longer used by Awka people. The belief in such a name has gone into antiquity because, the market day the child was born on is no longer considered when choosing a name for the baby. This may be the reason why stealing at market places is now rampant.

\section{Nwokeabia (a son has come)}

This name signifies that the family waited for so long before the arrival of a baby boy. This shows the state of mind of our fore - fathers. It shows that nature is the giver of children whether male or female. Our fore-fathers had no scientific knowledge about in-vitro fertilization; a rigorous and painful procedure but, they had their natural ways of doing that and also believed that the giver of life will give them male children and most often they were given. But, today, with all the technological know-how more women suffer from infertility; more so, many people do not give birth to baby boys as they used to before the invasion of modernity into their lives.

\section{Udeozo (the glory of Ozo title)}

This name shows the soft life of primitive people. They simply organized their community by making $O z O$ titled men to be custodians of culture. Ozo titled men have rights, privileges, duties and codes of behaviour. The title is the closet an Awka man could get to be a king. Before the advent of the white man, they held judicial and executive responsibilities. The title is a sign of coming of age of an individual. There was nothing like lawyers, police men etc. the people had their simple way of settling dispute hence crime rate was extremely low and nearly non-existent.

\section{Nwobukaibeya (lineage that is greater than others)}


Our fore-fathers believed so much in lineage and this is the reason why our forefathers were afraid to do bad things in order not to soil the image of their home. They believed so much that posterity will judge them. Some lineages are known for their truthfulness while some were known for their hard-work, hence, the name Nwobukaibeya . This philosophy is no longer in existence and men are now judged not by their character but by the number of cars and houses that they have; whether gotten legally or illegally. Simple primitive lifestyle promoted genuine hard-work while, modernity promotes fraud at all level.

\section{Nwaugoye (beautiful girl of Oye)}

Ugo is 'an eagle' and it is regarded as a beautiful and glorious animal and the names depict the reality of Oye market day. Onukawa (2000) observes that names of market days are gender specific because men are associated with deities, death, greatness, revered title while women are associated with goodness. Women are regarded as nature's best art and they are taken care of like eggs. But, in modern world, the slogan "what a man can do, a woman can do better" has affected the mentality of modern women so much that they have lost the tenderness and love nature bestowed on them. This may be the reason why most modern women are breadwinners in their home.

\section{Nwaoyeokaebede (child born on Oye day Ebede is a market square)}

The name depicts the location where a child was born which is in a large market square. In the primitive era, large squares were provided for village markets, meetings or festivals and Ebede was one of them. Life was simple but fun for our grandfathers. But with the advent of globalization, such squares have disappeared, houses and industries have occupied such squares and that natural and friendly environment our fore-fathers enjoyed has gone.

\section{Okwike (harsh word is not good)}

This name is largely used to caution people to be mindful of what they say which could hurt the feelings of other people. This is because when negative things are said about an individual, it could lead to heart attack. Primitive people believed so much in peaceful and friendly coexistence. Unlike, the present world, where people intentionally say hurtful things to one another such as the use of hate speeches for cyber/ social media bullying; this maybe the cause of high rate of suicide and mental illness in modern world.

\section{Ejiofo (a truthful person)}

It should be noted that the name is now used mostly as surnames and not first names. Primitive people believed so much in integrity and truth. A truthful man used to be celebrated and given respect and sensitive things to handle in the village. Such people were trusted by people. Unfortunately, in modern day Awka, being truthful is no longer a virtue but rather it is seen as naivety.

\section{Okoludo (A man of peace)}

This name depicts the primitive nature and lifestyle of our fore-fathers. They believed in peaceful and friendly life. A peaceful life brings joy and happiness and not war. However, such a name is no longer in existence. With the advent of civilization and globalization people now see peaceful people as cowards.

\section{Awka Names in the Face of Globalization}

As Awka culture interacts with one another, there are bound to be impact. Impact could be positive or negative. Globalization has given rise to global culture and global culture has had negative impact on the names Awka people once bore. All the cultural values once cherished by the people had been given up for western cultural values. English names now occupy an enviable position in our community. Invariably, English has become the global language and our culture is bound to be displaced. Our youth have been culturally colonized and they now imitate patterns of the Europeans, their language and naming pattern with no regard for the local culture. This is the reason why succession is no longer practiced. In fact, children insist that their 
parents should disown them and if the parents did not yield to the pressure, they become intolerable and may abscond without keeping in touch with their parents. Many on the other hand, force their parents to sell their family house and in turn, travel outside the country to find greener pastures with the money made from the sale. For some, they refuse to get married therefore will not procreate. Women no longer have a place in their father's compound. If a woman is unmarried, her brothers would frustrate her so that she will leave the family compound and will not have a share in her father's estate. If the woman dared give birth to a bastard, her father would quickly disown her. Globalization has obviously affected our value system. Those valued areas of our fore-fathers' lives have been abused and jettisoned by modernity; cultural norms are now thrown to the dustbin.

A closer look at the market days which were once used by the people to count the days of the week has been abandoned. Although Eke and Nkwo markets are still in existence, they are better to be called international markets. All the respect and spirituality which made up these markets are no longer recognized. The youths do not know the stories behind the market days and why the people of old took pride in even answering the names of the market days. This development is unfortunate, because culture sharpens the behaviour of man. Fafunwa (1991) as cited in Okeme (2008) states that "a people with no knowledge of their past would suffer from collective amnesia, groping blindly into the future without guide posts of precedence". The Awka man's pride was once in Ozo title taking, sadly, the wind of globalization has blown away such a rich culture especially among the younger generation who see it as a paganistic practice. The fashionable names in this era of globalization are names that do not tell stories about the people and may sometimes be considered "meaningless" such as: Jennifer, Lynda (snake), Jenny, Stephanie, Maureen, Hope, Wisdom, Redemption, Love, Favour, Oscar, Will, Gold, Patra, etc. Even when they choose to answer Igbo names, they use names that do not say anything about Awka culture or tradition which they tag as unique names some of the names are: Kamharida "may I not fall; Echioma "brighter tomorrow"; Enyichukwu "God's friend"; Somnazu "walk behind me"; Oluemunso "it is close to me".

\section{Conclusion}

The paper attempted primitivism theory on the analysis of Awka names. The study has indicated that names in traditional setting reflected the socio-cultural belief of their forefathers. Based on the above, the researcher concludes that globalization has negative impact on the names of the people which invariably have led to the death of Awka culture.

\section{References}

Akpotor, A. (2005). Deregulation and Globalization in Nigeria: Issues and Perspective. Benin City: Mora Mon Bros Ent.

Alege, T. (2008). Socio-Semantic Investigation of some Yoruba and English Names. In

A. Menegbe \& G. Omachonu (Eds.), Cultural Renaissance and National Development in the $21^{\text {st }}$ Century. (pp.76 -83). Abuja, Nigeria: Roots Books.

Algeo, J. (2010). Is a theory of names possible? Names: A Journal of Onomastics, 58.

(2), $90-96$.

Crystal, D. (1997). The Cambridge Encyclopedia of Language. Cambridge: Cambridge University Press.

Enojo, E.(2008). Globalization and the Culture of Third World Economy: Implications for National Development. In A. Menegbe \& G. Omachonu (Eds.), Cultural Renaissance and National Development in the $21^{\text {st }}$ Century, (pp. 46 -57). Abuja, Nigeria: Roots Books.

Gyekye, K. (1997). Tradition and Modernity. Oxford: Oxford University Press.

Lawal, K.O. The Impact of Globalization on Economic and Cultural Development of Nigeria. In O. Ndimele (Ed.), Globalization and the Study of Languages in Africa, (pp.12 -14). Port Harcourt, Nigeri :Grand Orbit Publications and Emhai Press. 
Lovejay, A. \& Boas, G. (1935). Primitivism and Related Ideas in Antiquity. Baltimore: John Hopkins Press

Makoni B., Makoni, S, \& Pfukwa, C. (2010). Language Planning, Language Ideology and Entextualization: War Naming Practices. Names: A Journal of Onomastics, 58.( 4), 197 - 208.

Mensah, E. (2015). Personal Names in Language Contact Situations: A Case of Cross River State Southeastern Nigeria. Anthropological Notebooks, 19 (3), 41 59.

Mmadike, B. (2014). Anthropolinguistic Study of Ala names in Igbo. IOSR Journal of Humanities and Social Sciences,9. (10), $11-19$.

Obeng, S. (1998). Akan Death Prevention Names: A Pragmatic and Structural analysis. Names: A Journal of Onomastics, 46.( 3), 163 - 187.

Offodile, E.P. (1998). A Pedigree of Awka and its People. Awka: Kucena - Damian Nigeria Limited.

Okeme, A. (2008). Effects of Western Education on Culture: The Nigerian Experience. In A. Menegbe \& G. Omachonu (Eds.), Cultural Renaissance and National Development in the $21^{\text {st }}$ Century,. (pp.263 - 274) Abuja, Nigeria: Roots Books.

Onukawa, M. (2000). The chi Concept in Igbo Gender Naming. Africa, 70 (1), 107117.

Staszak, J. (2004). Primitivism and the other. History of Art and Cultural Geography Geo Journal, 60, 353 - 364.

Udoh, I. (2007). Globalization and the Reservation of Nigerian languages. In O. Ndimele (Ed.), Convergence: English and Nigerian Languages, (pp. 193-202). Port Harcourt, Nigeria :Grand Orbit Publications and Emhai Press.

Udoye, I. (2018). A Linguistic Appraisal of Igbo Anthroponyms. Journal of Lexicography and Terminology, 2 (1) 1 19.

Udoye, I.E. ( 2018). The Semantics of Oka Dying Anthroponyms. Onomastica Uralica 11, 259 - 284
Yusuf, M. (2008). Culture and Cultural Change among the Igala People. In A. Menegbe \& G. Omachonu (Eds.), Cultural Renaissance and National Development in the $21^{\text {st }}$ Century, (pp. 252- 256). Abuja, Nigeria: Roots Books. 